\title{
Study on Physical Education Reform in Colleges and Universities under the Background of Ideological and Moral Education
}

\author{
Gang Yan \\ Changzhou Vocational Institute of Textile and Garment Changzhou, Jiangsu, 213164
}

Keywords: teaching thinking; ideological and moral education; college sports; teaching reform; method exploration

\begin{abstract}
The course of sports is one of the compulsory courses in colleges and universities. With the development of the society and the progress of educational concepts, the physical education teaching in colleges and universities has begun to implement reforms. However, it is necessary for reform to first consider its direction and guiding ideology and establish a correct value orientation. Ideological and moral education is currently the guiding ideology for many colleges and universities to carry out sports reform, which is not only a need for students to exercise their bodies, but also a need for students to keep up with the pace of development of the times, and it is also a need for students to realize the healthy development of ideology. This paper focuses on the analysis of how to use ideological and moral education as a guiding ideology to lead colleges and universities to implement the teaching reform of sports.
\end{abstract}

\section{Introduction}

When the concept of national fitness and national sports began to enter the hearts of people, colleges and universities began to work on the teaching reform of physical education curriculum. However, the purpose of carrying out physical education teaching is not only to allow students to learn sports skills and physical exercise. In fact, the focus of physical education reform is to cultivate students' unremitting sportsmanship, so as to achieve students' all-round development. Therefore, the current implementation of physical education teaching reform should be ideological and moral education as the guiding ideology of teaching reform, under the guidance of this idea, we can scientifically promote the scientific teaching reform in colleges and universities. Here we discuss this.

\section{Current Problems in College Sports Teaching}

College sports is a key part of teaching throughout the entire university. It plays an important role in promoting students' ability to develop in all aspects and promote students' physical and mental development. However, there are still many problems in the status quo of the physical education in the former colleges and universities, which are mainly manifested in the following aspects:

Nowadays, there are misunderstandings in the teaching of physical education teachers in colleges and universities. The training of students' physical ability and skills is taken as the teaching goal and teaching focus of this lesson, that is, they only pay attention to the students' achievements and whether they complete the teaching tasks of this lesson. However, while ignoring the cultivation of sportsmanship, in teaching, he only taught basic sports skills, but did not implement the sportsmanship to students, resulting in the entire teaching process being mechanized but without connotation and ideology. For example, the "jogging" lesson in the basic university curriculum requires teachers to teach jogging breathing, swinging arms, and other techniques. It also encourages students to overcome the spirit of persistent fatigue, but many teachers fail to do so. Make it happen.

In the course of competition training, the value-oriented education has not been valued. This has led to problems in the values of the students. The concept of winning and losing is extremely 
important. Students do not attach importance to sportsmanship and sportsmanship and even engage in vicious competition during competitions. Teachers at this time did not attach importance to education and counseling. Students were left in a state of indifference. The narrow sentiments of individualism, individual hero worship, bullying, and selfishness began to spread. This was unfavorable to the cultivation of students' world outlook, outlook on life, and values. For example, in basketball teaching, basketball is a sport that needs to follow rules and order, and it is very easy to arouse the students' desire to win. However, many teachers neglect the guidance of values and cause many students to commit malicious acts such as malice. .

Because some teachers believe that college students already have basic values and do not pay attention to the guidance of students, and that some sports teachers do not attach importance to the cultivation of sports spirit, students' psychology is affected by this sloppy order. The curriculum is carried out in a sloppy and disorderly environment. This is detrimental to the development of students' mental health, and the role of physical education teaching will be weakened.

\section{Ideological and Moral Education to Lead the Reform of Physical Education Curriculum}

The improvement of college students' moral qualities is one of the tasks of moral education in colleges and universities. As an important part of college education, physical education has become the carrier of moral education [1]. There are many sports events and the scope is very extensive. Each project has its own characteristics. There are also differences in the connotation and spirit of each project. Therefore, teachers should combine the moral education of students and practical teaching projects when teaching content is being taught, so as to achieve the dual combination of sports skill teaching and ideological and moral quality cultivation, and to use the guidance method. This is the physical education curriculum. Teaching gives a deeper meaning. For example, the "middle and long distance run" project in the basic university course is a compulsory subject for college sports, but it takes a lot of perseverance and endurance to complete this project, and many students therefore have to produce this course. Rejection psychology. In fact, this training program is precisely the training of students' perseverance and endurance, and it is also the cultivation of the students' hard-working spirit. Therefore, in the specific teaching process, teachers should take courses from this perspective. They can use real-life examples such as Zheng Jin, a Chinese player. Although they are disabled, they can still break the world record. This allows many college students to have a Challenges and desires for completion; at the same time, teachers must actively guide students to face difficulties and do their best to complete them. After the student has overcome his fear, the teacher is assisted with technical guidance and encourages and encourages the student during the training. After the training, the student can get a great feeling, so that this project's training goals and moral education goals are both Can finish.

In addition, some additional training or game sessions can be added to exercise the will of the students. This process can be completed by the game method, the classroom atmosphere is active, and the teaching goals are also completed. Two-man three-legged races and other games are good examples. After the students complete help and cooperate with each other, the students will help each other and care for each other, cultivating the team spirit and collective support of the students.

In terms of teaching methods and teaching methods, physical education teachers in colleges and universities must try to change the mode of thinking, do not use performance indicators as a key criterion for measuring students, but must stand in an equal perspective to observe and discover the needs of students, so as to be equal to students. From the perspective of teaching, to create a good teaching atmosphere and teaching environment. When teaching athletics projects, we must use the moral education idea as the guiding ideology. Teachers should not be too tangled in the outcome of students or their achievements. Instead, they should require students to do their best to complete the competition based on the observance of sports rules and sportsmanship. Projects, so that successful people do not appear to be proud of complacency. After competitions or exercises are completed, pay attention to letting students summarize their own gains and problems. This achieves the dual effects of frustration education and self-summarizing education. This kind of self-summarizing spirit and ability is very helpful for students to enter the society. Take the lesson in the basic course 
"Basketball” as an example. When teachers organize students to shoot a game, they must encourage students to be even in their minds and pay attention to skills in shooting, rather than focusing on the outcome of the shooting. For students who have achieved good results, they should teach students to guard against arrogance and arrogance and strive to improve; for students with poor performance, students should be encouraged to self-summarize, standardize their movements, improve their skills, and strive to achieve better results.

Today's college students live in an era of rapid development in all aspects. During this period, students pay attention to individual development, pay attention to self-development, and easily accept new things and new ideas. However, students at this stage lack judgment ability and screening ability. At the same time, the proportion of one-child children is relatively large. Since childhood, they have grown up under the care of their fathers, seldom have their own independence. Therefore, their ability to work and their ability to do things are often hesitant. Physical education courses are open and free of price, which makes it difficult for teachers to teach. This requires teachers in the classroom, pay attention to the details of the teaching, and pay attention to the students' psychological changes. Once a student has escaped or evades emotions or even rejects classes, teachers must guide them in a timely manner. By changing teaching methods, adjusting classroom atmosphere, or adding fun games, students can increase their interest in participating in the class and subtly influence students' moral qualities. influences. Taking the lesson of "Sports Health Care Knowledge" as an example, this is a relatively boring theoretical course. Students can easily create a rejection mentality and think that the course is boring. At this time, teachers should pay attention to adjusting the classroom atmosphere. The teacher can find two students to come to the front to practice the wound healing method. One student plays the wounded and one student plays the first responder. After observation, other students point out what problems the first responder has when handling the wounded. Adopting this teaching method can not only cultivate students' hands-on skills, but also allow students to concentrate on achieving the purpose of adjusting classroom atmosphere and alleviating students' emotions. It is also a kind of training for students' collaborative spirit.

Teachers are a special presence for many students because teachers are one of the objects that students imitate. Different students have different ways of doing things, thinking and character. When teachers teach students knowledge, students will naturally imitate the behavior of teachers. This means that teachers are very good examples for college students. Role. In the process of physical education reform, teachers play a crucial role in improving students' moral quality. Therefore, teachers should pay attention to their own quality and behavior, and constantly improve and develop themselves, so as to give students a positive and positive impact. At the same time, teachers should only set an example and conduct ideological and moral education for students when they conduct physical education. More persuasive and influential. When carrying out teaching work, physical education teachers in colleges and universities should pay attention to the role of full play of role models. No matter whether they are talking or behaving, they must be models of student imitation [2]. When teachers infect students, they also strictly enforce themselves so that they can train qualified personnel who are qualified in all fields.

\section{The Necessity of Ideological and Moral Education to Lead the Physical Education Curriculum Reform}

For people's own development, sports is a sports task that requires one's dedication and dedication. Therefore, when a person participates in sports and makes various movements, whether it is psychological or physical changes naturally occur. Have to accept, sports will bring us a sense of fatigue, but how to overcome this sense of fatigue and stick to it is now a lot of college students need to face the problem. Sports must be conducted on a regular and continuous basis. This requires students to be guided ideologically at the time of exercise so that they can have the conviction to overcome everything and persevere, so that they can develop hard-working and tough students. Uncompromising and indomitable moral qualities. Reflected in physical education teaching, teachers should encourage students to build confidence while teaching students to improve their 
skills. Students have the courage to overcome difficulties, skills to promote the effectiveness of teaching, and can promote the good personality of students. At the same time, in terms of the guiding ideology of sports itself, the higher, faster and stronger guiding ideology can play a very encouraging role. Students experience a sense of accomplishment and honor in the competition; many items in sports All need to be completed collaboratively. This requires students to have a sense of competition and a sense of cooperation. Therefore, moral education in PE teaching is bound to arouse the attention of teachers and students.

Physical education courses are not only diverse in content but also relatively free in form and have distinctive characteristics. Therefore, the process of physical education can also be seen as a process of shaping students' good moral qualities. There are group exercises and team competitions in the sports. These projects can help students to strengthen mutual trust. At the same time, they are also a way of cultivating students' collective sense of honor and team centripetal force; single-person projects such as high jump and long jump can cultivate students' aggressiveness. The spirit of courage. In addition, the scope of physical education curriculum activities takes a large proportion of the time, which requires students to have a certain degree of self-discipline, which is consistent with the requirements of the spirit of the sport to comply with the rules. Students get more fun in specific sports learning and practice, have a positive effect on students' physical and mental development, and can also shape students' optimistic and confident quality [3]. Therefore, teachers should respect classroom rules and disciplines and develop good self-study habits as the focus of the curriculum so that students can develop a good spirit of self-discipline.

\section{Conclusion}

The reason why there are many problems in current physical education teaching in colleges and universities is that today's physical education curriculum in colleges and universities is still heavily influenced by the concept of exam. It is only using performance as a key criterion to measure whether students' physical education standards are met. However, this measure ignores the moral guidance of physical education, but focuses on the form of teaching, but ignores the final teaching content. Therefore, the college curriculum reform needs the key idea of moral education as the guiding thought of teaching reform.

\section{References}

[1] Yu Wenqian. Exploration of moral training function in college physical education[J]. Education and Teaching Forum, 2017(35):22-23.

[2] Zhao Zhenhu. Analysis of role of physical education teacher in model education[J]. Examination Weekly, 2017(46):136.

[3] Yu Wenqian. Exploration of moral training function in college physical education[J]. Education and Teaching Forum, 2017(35):22-23. 